\title{
Morphometric and Meristic Analysis of Tor putitora (Hamilton Buchanan) from Ujh River, Kathua (J\&K)
}

\author{
Monika Bansal ${ }^{1}$ • Ankush Sharma ${ }^{1} \cdot \operatorname{Ram~Krishan}^{* 2} \cdot$ Rajesh Kumar $^{3}$ • A. K. Dobriyal ${ }^{4}$ \\ ${ }^{1}$ Department of Zoology, Sri Sai University, Palampur, H.P \\ ${ }^{2}$ Department of Zoology, Govt. Degree College, Kathua $(J \& K)$ \\ ${ }^{3}$ Department of Zoology, Himachal Pradesh university, Shimla \\ ${ }^{4}$ Department of Zoology, HNB Garhwal University Campus Pauri Garhwal 246001, Uttarakhand \\ *Corresponding author: rkjarngal@gmail.com
}

Received: 21.7.2021; Revised: 9.8.2021; Accepted: 22.8.2021

OSociety for Himalayan Action Research and Development

\begin{abstract}
The morphology of fishes has been the major source of information for taxonomic and evolutionary studies. The present communication deals with the taxonomic analysis of Golden Mahseer- Tor putitora, collected from river Ujh, a tributary of Ravi in District Kathua, (Jammu \& Kashmir). The morphological characters are generally divided into two major categories, the morphometric and the meristic. For morphometric studies the parameters considered were: the total length, standard length, head length, pre-dorsal length, pre-ventral length, pre-anal length, caudal length, snout length, eye diameter and maximum body depth. The growth of parameters were studied in relation to three independent variables, i.e., total length, standard length and the head length. Meristic counts of fin rays and fin spines etc. were also studied.
\end{abstract}

Key words: Tor Putitora, Morphometric analysis, Meristic analysis, Growth interdependency

\section{Introduction}

Taxonomy is an important aspect of fish biology. The identification of fish is based on inter-relationships of morphometric and meristic characters apart from some morphological characters.. Golden Mahseer (Tor putitora) is the most commercial fish of Jammu \& Kashmir. It is generally known as a game fish and found all along the Himalayan region inhabiting different rivers throughout the length and breadth in India, Pakistan, Bangladesh, Srilanka and even Thailand (Thomas 1897). In India, it is found in Jammu \& Kashmir, Himachal Pradesh, Uttarakhand, Uttar Pradesh, Bihar, Assam, West Bengal, Sikkim, Manipur, Meghalaya and Nagaland. The National Commission on Agriculture (1976) in its report on fisheries has stated that there was a decline in mahseer fishery in India due to indiscriminate fishing of broods and juvenile as well as due to adverse effects of dams. A considerable decline in mahseer fishery in lakes and streams of Northern region has also been reported from time to time by number of workers by (Jhingran and Sehgal, 1978; Joshi et al., 1978; Sehgal, 1983). The present study is designed with an objective to study the taxonomic aspects of Tor putitora and variability, if any.

\section{Material and Methods}

A total number of 30 specimens of Tor putitora were collected from river Ujh, Kathua district of Jammu and Kashmir with the help of standard fishing gears from January(2020) to June(2020). The specimens were preserved in $5 \%$ formalin solution on the spot and were brought to the laboratory for further analysis. The meristic counts and morphometric measurements were recorded within 48 hours 
of collection to avoid any shrinkage due to preservation.

Morphometric Study: For morphometric study of Tor putitora, the parameters considered were the total length, standard length, head length, pre-dorsal length, preventral length, pre-anal length, caudal length, snout length, eye diameter and maximum body depth. These (pre-dorsal length, pre-ventral length, pre-anal length, caudal length, snout length, eye diameter and maximum body depth) variables were studied in relation to total length, standard length and head length separately as per taxonomy requirement. Fish measurement board and sharp pointed dividers were used for taking body measurements.

Meristic Study: Meristic counts of the characters like fin rays and fin spines etc. were also studied with the help of fine forceps and hand lens. The observed characters were compared / verified with the help of Talwar and Jinghran (1991).

Regression Analysis: Characters were analysed with the help regression analysis ( $\mathrm{Y}$ $=\mathrm{a}+\mathrm{bX}$ ) where $\mathrm{Y}$ is the dependent variable and $\mathrm{X}$ is the independent variables like Total length, Standard length and Head length individually. "a" is the intercept and " $b$ " is the regression coefficient or slope.

\section{Results}

Morphometrics characters of Tor putitora are summarized in Table 1. The minimum sample size of fish being 5 was considered in size group $35-40 \mathrm{~cm}$ and maximum 9 in the size group $25-30 \mathrm{~cm}$ and $20-25 \mathrm{~cm}$.

Statistics regarding how body parameters grow in ratio of total length is presented in Table 2. The ratio of total length and standard length fluctuated in between $1.18 \pm 0.05: 1$ in size group 35 to $40 \mathrm{~cm}$ to a maximum of $1.2 \pm$ 0.06:1 in the size group of 20 to $25 \mathrm{~cm}$. Ratio of total length and head length fluctuated from $5.44 \pm 0.28: 1$ in the length group of 25 to 30 $\mathrm{cm}$ to a maximum of $5.94 \pm 0.19: 1$ in the length group of 35 to $40 \mathrm{~cm}$. Ratio of total length to pre dorsal length was minimum 2.49 $\pm 0.09: 1$ in the size group 30 to $35 \mathrm{~cm}$ and maximum $2.88 \pm 0.21: 1$ in the size group 35 to $40 \mathrm{~cm}$. Ratio of total length to pre pectoral length was minimum $4.9 \pm 0.33: 1$ in the size group 20 to $25 \mathrm{~cm}$ and maximum $6.02 \pm$ 0.31:1 in the size group 35 to $40 \mathrm{~cm}$. Ratio of total length to pre pelvic length was minimum $2.45 \pm 0.1: 1$ in the size group 25 to $30 \mathrm{~cm}$ and maximum $2.88 \pm 0.33: 1$ in the size group 35 to $40 \mathrm{~cm}$. Ratio of total length to pre anal length was minimum $1.62 \pm 0.06: 1$ in the size group 20 to $25 \mathrm{~cm}$ and maximum $1.92 \pm 0.1: 1$ in the size group 35 to $40 \mathrm{~cm}$. Ratio of total length to eye diameter was minimum $29.65 \pm 4.37: 1$ in the size group 25 to $30 \mathrm{~cm}$ and maximum 37.9 $\pm 4.77: 1$ in the size group 35 to $40 \mathrm{~cm}$. Ratio of total length to snout length was minimum $21.52 \pm 1.72: 1$ in the size group 20 to $25 \mathrm{~cm}$ and maximum $25.3 \pm 1.05: 1$ in the size group 35 to $40 \mathrm{~cm}$. Ratio of total length to maximum body depth was minimum $5.99 \pm 0.6: 1$ in the size group 30 to $35 \mathrm{~cm}$ and maximum $6.48 \pm$ $0.35: 1$ in the size group 20 to $25 \mathrm{~cm}$. Ratio of 
total length to caudal length was minimum $4.73 \pm 0.09: 1$ in the size group 20 to $25 \mathrm{~cm}$ and maximum $5.34 \pm 0.29: 1$ in the size group 35 to $40 \mathrm{~cm}$.

Table 1: Summarized Data on the Mophometrics of Tor putitora

\begin{tabular}{|c|c|c|c|c|c|c|c|c|c|c|c|c|c|}
\hline S.No. & $\begin{array}{c}\text { Size } \\
\text { Groups } \\
\text { (cm) }\end{array}$ & TL & SL & HL & PDL & PPL & PVL & PAL & ED & SL & MBD & CL & $\begin{array}{l}\text { No. of } \\
\text { fish }\end{array}$ \\
\hline 1 & $20-25$ & $\begin{array}{c}21.52 \pm 1 \\
.72\end{array}$ & $\begin{array}{l}18 \pm 1 \\
44\end{array}$ & $\begin{array}{c}3.89 \pm \\
0.26\end{array}$ & $\begin{array}{l}8.4 \pm \\
0.65\end{array}$ & $\begin{array}{c}4.41 \pm 0 . \\
47\end{array}$ & 8. & $\begin{array}{c}13.3 \pm 0 \text {. } \\
84\end{array}$ & $\begin{array}{c}0.73 \pm 0 \\
.18\end{array}$ & $1 \pm 0$ & $\begin{array}{c}3.32 \pm 0 \\
.24\end{array}$ & $\begin{array}{c}4.56 \pm \\
0.37\end{array}$ & 9 \\
\hline 2 & $25-30$ & $\begin{array}{c}27.18 \pm 1 \\
.23\end{array}$ & $\begin{array}{l}22.61 \\
\pm 1.54\end{array}$ & $\begin{array}{c}5.01 \pm \\
0.35\end{array}$ & $\begin{array}{l}10.54 \\
\pm 0.47\end{array}$ & $\begin{array}{c}5.58 \pm 0 . \\
58\end{array}$ & $\begin{array}{c}11.09 \pm 0 . \\
36\end{array}$ & $\begin{array}{c}16.12 \pm 0 \\
.41\end{array}$ & $\begin{array}{c}0.93 \pm 0 \\
.13\end{array}$ & $\begin{array}{c}1.17 \\
\pm 0.2 \\
5\end{array}$ & $\begin{array}{c}4.32 \pm 0 \\
.36\end{array}$ & $\begin{array}{c}5.64 \pm \\
0.15\end{array}$ & 9 \\
\hline 3 & $30-35$ & $\begin{array}{c}30.79 \pm 1 \\
.78\end{array}$ & $\begin{array}{l}26.04 \\
\pm 1.56\end{array}$ & $\begin{array}{c}5.61 \pm \\
0.38\end{array}$ & $\begin{array}{l}12.36 \\
\pm 0.85\end{array}$ & $\begin{array}{c}6.07 \pm 0 . \\
31\end{array}$ & $\begin{array}{c}12.54 \pm 0 . \\
88\end{array}$ & $\begin{array}{c}18.01 \pm 1 \\
.34\end{array}$ & $1 \pm 0$ & $\begin{array}{c}1.41 \\
\pm 0.1 \\
9\end{array}$ & $\begin{array}{l}5.17 \pm 0 \\
.49\end{array}$ & $\begin{array}{c}5.81 \pm \\
0.32\end{array}$ & 7 \\
\hline 4 & $35-40$ & $\begin{array}{c}37.9 \pm 1 \\
14\end{array}$ & $\begin{array}{c}32.2 \pm \\
2.17\end{array}$ & $\begin{array}{c}6.38 \pm \\
0.16\end{array}$ & $\begin{array}{c}13.2 \pm \\
0.84\end{array}$ & $\begin{array}{c}6.3 \pm 0.2 \\
7\end{array}$ & $\begin{array}{c}13.3 \pm 1.6 \\
4\end{array}$ & $\begin{array}{c}19.8 \pm 0 . \\
84\end{array}$ & $1 \pm 0$ & $\begin{array}{l}1.5 \pm \\
0.07\end{array}$ & $\begin{array}{c}5.88 \pm 0 \\
.11\end{array}$ & $\begin{array}{c}7.12 \pm \\
0.57\end{array}$ & 5 \\
\hline
\end{tabular}

$T L=$ Total length, $S L=$ Standard length, $H L=$ Head length, Snt. $L=$ Snout length, MBD=Max.Body depth, $P A L=$ Pre anal length, $P D L=$ Pre dorsal length, $P V L=$ Pre Ventral length, $E D=E y e$ diameter, $C L=$ Caudal length

Table 2: Growth of different body lengths in ratio of Total Length of Tor putitora

\begin{tabular}{|c|c|c|c|c|c|c|c|c|c|c|c|}
\hline SN & $\begin{array}{c}\text { Size } \\
\text { groups } \\
(\mathrm{cm})\end{array}$ & SL & HL & PDL & PPL & PVL & PAL & ED & Sn.L & MBD & CL \\
\hline 1 & $20-25$ & $\begin{array}{c}1.2 \pm 0 . \\
06\end{array}$ & $\begin{array}{c}5.54 \pm 0.2 \\
5\end{array}$ & $\begin{array}{c}2.56 \pm 0.0 \\
8\end{array}$ & $\begin{array}{c}4.9 \pm 0.3 \\
3\end{array}$ & $\begin{array}{c}2.49 \pm 0 . \\
08\end{array}$ & $\begin{array}{c}1.62 \pm 0.0 \\
6\end{array}$ & $\begin{array}{c}30.48 \pm 5 . \\
4\end{array}$ & $\begin{array}{c}21.52 \pm 1.7 \\
2\end{array}$ & $\begin{array}{c}6.48 \pm 0.3 \\
5\end{array}$ & $\begin{array}{c}4.73 \pm 0 \\
.09\end{array}$ \\
\hline 2 & $25-30$ & $\begin{array}{c}1.2 \pm 0 . \\
05\end{array}$ & $\begin{array}{c}5.44 \pm 0.2 \\
8\end{array}$ & $\begin{array}{c}2.58 \pm 0.0 \\
4\end{array}$ & $\begin{array}{c}4.9 \pm 0.3 \\
3\end{array}$ & $\begin{array}{c}2.45 \pm 0 \\
.1\end{array}$ & $\begin{array}{c}1.69 \pm 0.0 \\
4\end{array}$ & $\begin{array}{c}29.65 \pm 4.3 \\
7\end{array}$ & $\begin{array}{c}24.08 \pm 4.2 \\
7\end{array}$ & $\begin{array}{c}6.31 \pm 0.3 \\
8\end{array}$ & $\begin{array}{c}4.82 \pm 0 \\
.19\end{array}$ \\
\hline 3 & $30-35$ & $\begin{array}{c}1.18 \pm 0 . \\
07\end{array}$ & $\begin{array}{c}5.51 \pm 0.4 \\
8\end{array}$ & $\begin{array}{c}2.49 \pm 0.0 \\
9\end{array}$ & $\begin{array}{c}5.08 \pm 0.3 \\
7\end{array}$ & $\begin{array}{c}2.46 \pm 0 . \\
13\end{array}$ & $\begin{array}{c}1.71 \pm 0.0 \\
7\end{array}$ & $\begin{array}{c}30.79 \pm 1.7 \\
8\end{array}$ & $\begin{array}{c}22.16 \pm 3.6 \\
5\end{array}$ & $\begin{array}{c}5.99 \pm 0 . \\
6\end{array}$ & $\begin{array}{l}5.3 \pm 0 . \\
33\end{array}$ \\
\hline 4 & $35-40$ & $\begin{array}{c}1.18 \pm 0 \\
.05\end{array}$ & $\begin{array}{c}5.94 \pm 0.1 \\
9\end{array}$ & $\begin{array}{c}2.88 \pm 0.2 \\
1\end{array}$ & $\begin{array}{c}6.02 \pm 0.3 \\
1\end{array}$ & $\begin{array}{c}2.88 \pm 0 . \\
33\end{array}$ & $\begin{array}{c}1.92 \pm 0 . \\
1\end{array}$ & $\begin{array}{c}37.9 \pm 1.1 \\
4\end{array}$ & $25.3 \pm 1.05$ & $\begin{array}{c}6.45 \pm 0.2 \\
4\end{array}$ & $\begin{array}{c}5.34 \pm 0 \\
.29\end{array}$ \\
\hline & erage & $\begin{array}{c}1.19 \pm 0 \\
.06\end{array}$ & $\begin{array}{c}5.57 \pm 0.3 \\
5\end{array}$ & $\begin{array}{c}2.6 \pm 0.1 \\
6\end{array}$ & $\begin{array}{c}5.13 \pm 0.5 \\
2\end{array}$ & $\begin{array}{c}2.54 \pm 0 . \\
22\end{array}$ & $\begin{array}{c}1.71 \pm 0.1 \\
2\end{array}$ & $\begin{array}{c}31.54 \pm 4.7 \\
7\end{array}$ & & $\begin{array}{c}6.31 \pm 0.4 \\
4\end{array}$ & $\begin{array}{c}4.99 \pm 0 \\
.35\end{array}$ \\
\hline
\end{tabular}

Body parameters in ratio of standard length were calculated and presented in Table 3 . The ratio of standard length and head length fluctuated from a minimum $4.52 \pm 0.15: 1$ in the size group of 25 to $30 \mathrm{~cm}$ to a maximum of $5.05 \pm 0.35: 1$ in the size group of 35 to 40 $\mathrm{cm}$. Ratio of standard length to pre dorsal length was minimum $2.12 \pm 0.018: 1$ in the size group of 30 to $35 \mathrm{~cm}$ and maximum $2.45 \pm$ $0.27: 1$ in the size group 35 to $40 \mathrm{~cm}$. Ratio of standard length to pre pectoral length was minimum $4.07 \pm 0.17: 1$ in the size group 25 to $30 \mathrm{~cm}$ and maximum $5.12 \pm 0.14: 1$ in the size group 35 to $40 \mathrm{~cm}$. 
Table 3: Growth of different Body Parts in ratio of Standard Length in Tor putitora

\begin{tabular}{ccccccccccc}
\hline SN & $\begin{array}{c}\text { Size } \\
\text { Groups } \\
(\mathbf{c m})\end{array}$ & HL & PDL & PPL & PVL & PAL & ED & SN. L & MBD & CL \\
& & & & & & & & & \\
\hline 1 & $20-25$ & $4.63 \pm 0$. & $2.14 \pm 0$. & $4.09 \pm 0$. & $2.09 \pm 0$. & $1.35 \pm 0.0$ & $25.4 \pm 4.0$ & $18 \pm 1.44$ & $5.42 \pm 0$. & $3.96 \pm 0$. \\
& & 28 & 11 & 21 & 09 & 4 & 5 & & 33 & 28 \\
2 & $25-30$ & $4.52 \pm 0$. & $2.14 \pm 0$. & $4.07 \pm 0$. & $2.04 \pm 0$. & $1.4 \pm 0.07$ & $24.66 \pm 3$. & $20.11 \pm 4$. & $5.25 \pm 0$. & $4.01 \pm 0$. \\
& & 15 & 08 & 17 & 12 & & 72 & 12 & 34 & 26 \\
3 & $30-35$ & $4.66 \pm 0$. & $2.12 \pm 0$. & $4.3 \pm 0.3$ & $2.08 \pm 0$. & $1.45 \pm 0.0$ & $26.04 \pm 1$. & $18.77 \pm 3$. & $5.06 \pm 0$. & $4.49 \pm 0$. \\
& & 41 & 18 & 7 & 13 & 6 & 56 & 33 & 4 & 41 \\
4 & $35-40$ & $5.05 \pm 0$. & $2.45 \pm 0$. & $5.12 \pm 0$. & $2.45 \pm 0$. & $1.63 \pm 0.1$ & $32.2 \pm 2.1$ & $21.48 \pm 1$. & $5.48 \pm 0$. & $4.53 \pm 0$. \\
& & 35 & 27 & 41 & 32 & 3 & 7 & 28 & 38 & 27 \\
\hline & Average & $4.67 \pm 0$. & $2.19 \pm 0$. & $4.3 \pm 0.4$ & $2.13 \pm 0$. & $1.44 \pm 0.1$ & $26.46 \pm 4$. & $19.39 \pm 3$. & $5.3 \pm 0.3$ & $4.19 \pm 0$. \\
& & 34 & 19 & 7 & 21 & 2 & 07 & 06 & 8 & 39 \\
\hline
\end{tabular}

$T L=$ Total length, $S L=$ Standard length, HL=Head length, Snt.L=Snout length, MBD=Max.Body depth, PAL=Pre anal length, $P D L=$ Pre dorsal length, $P V L=$ Pre Ventral length, $E D=$ Eye diameter, $C L=$ Caudal length

Ratio of standard length to pre pelvic length was minimum $2.04 \pm 0.12: 1$ in the size group 25 to $30 \mathrm{~cm}$ and maximum $2.45 \pm 0.32: 1$ in the size group 35 to $40 \mathrm{~cm}$. Ratio of standard length to pre anal length was minimum $1.35 \pm$ 0.04:1 in a length group 20 to $25 \mathrm{~cm}$ and maximum $1.63 \pm 0.13: 1$ in the length group 35 to $40 \mathrm{~cm}$. Ratio of standard length to eye diameter was minimum $24.66 \pm 3.72: 1$ in the size group 25 to $30 \mathrm{~cm}$ and maximum $32.2 \pm$ 2.17:1 in the size group 35 to $40 \mathrm{~cm}$. Ratio of standard length to snout length was minimum $18 \pm 1.44: 1$ in the size group 20 to $25 \mathrm{~cm}$ and maximum $21.48 \pm 1.28: 1$ in the size group 35 to $40 \mathrm{~cm}$. Ratio of standard length to maximum body depth was minimum $5.06 \pm$ $0.4: 1$ in the size group 30 to $35 \mathrm{~cm}$ and maximum $5.48 \pm 0.38: 1$ in the size group 35 to
$40 \mathrm{~cm}$. Ratio of standard length to caudal length was minimum $3.96 \pm 0.28: 1$ in the size group 20 to $25 \mathrm{~cm}$ and maximum $4.53 \pm$ $0.27: 1$ in the size group 35 to $40 \mathrm{~cm}$.

Body parameters in ratio of head length were calculated and presented in Table 4. The ratio of head length to eye diameter fluctuated from minimum $5.46 \pm 0.82: 1$ in the size group of 25 to $30 \mathrm{~cm}$ and maximum of $6.38 \pm 0.16: 1$ in a length group of 35 to $40 \mathrm{~cm}$. The ratio of head length to snout length was minimum $3.89 \pm 0.26: 1$ in size group 20 to 25 $\mathrm{cm}$ and maximum $4.46 \pm 0.93: 1$ in the size group 25 to $30 \mathrm{~cm}$. The ratio of head length to maximum body depth was minimum $1.09 \pm$ 0.02:1 in the size group 35 to $40 \mathrm{~cm}$ and maximum0.17 $\pm 0.03: 1$ in the size group 20 to $25 \mathrm{~cm}$.

Table 3.4: Growth of different Body parts in ratio of Head Length in Tor putitora

\begin{tabular}{ccccc}
\hline S.No. & Size groups $(\mathbf{c m})$ & Eye-Diameter & Snout-Length & Maximum Body depth \\
\hline 1 & $20-25$ & $5.51 \pm 0.97$ & $3.89 \pm 0.26$ & $1.17 \pm 0.03$ \\
2 & $25-30$ & $5.46 \pm 0.82$ & $4.46 \pm 0.93$ & $1.16 \pm 0.06$ \\
3 & $30-35$ & $5.61 \pm 0.38$ & $4.06 \pm 0.88$ & $1.09 \pm 0.08$ \\
4 & $35-40$ & $6.38 \pm 0.16$ & $4.26 \pm 0.28$ & $1.09 \pm 0.02$ \\
& Average & $5.67 \pm 0.77$ & $4.16 \pm 0.69$ & $1.14 \pm 0.06$
\end{tabular}


Regression analysis of various body parameters with total length, standard length and head length were calculated and statistical values of intercept (a), regression coefficient (b), coefficient of correlation(r) and coefficient of determination $\left(\mathrm{r}^{2}\right)$ are presented in table 5, 6 and 7 respectively.

\section{Table 3.5: Regression Analysis and Correlation Coefficient between Total Length and Dependent Parameters of Tor putitora}

\begin{tabular}{|c|c|c|c|c|c|}
\hline S.No. & Dependent parameter & $\begin{array}{c}\text { Intercept } \\
\text { (a) }\end{array}$ & $\begin{array}{c}\text { Regression } \\
\text { coefficient } \\
\text { (b) }\end{array}$ & $\begin{array}{c}\text { Correlation } \\
\text { coefficient } \\
\text { (r) }\end{array}$ & $\begin{array}{c}\text { Coefficient of } \\
\text { Determination } \\
\left(\mathbf{r}^{\mathbf{2}}\right)\end{array}$ \\
\hline 1 & Standard Length & -0.56 & 0.86 & 0.97 & 0.95 \\
\hline 2 & Head length & 0.76 & 0.15 & 0.94 & 0.89 \\
\hline 3 & Pre-Dorsal Length & 1.92 & 0.31 & 0.94 & 0.88 \\
\hline 4 & Pre-Pectoral Length & 1.94 & 0.12 & 0.85 & 0.72 \\
\hline 5 & Pre-Pelvic Length & 1.96 & 1.13 & 0.89 & 0.79 \\
\hline 6 & Pre-Anal Length & 4.71 & 0.41 & 0.96 & 0.92 \\
\hline 7 & Eye-Diameter & 0.37 & 0.02 & 0.67 & 0.40 \\
\hline 8 & Snout-Length & 0.30 & 0.03 & 0.76 & 0.58 \\
\hline 9 & Maximum Body depth & -0.01 & 0.16 & 0.94 & 0.88 \\
\hline 10 & Caudal Length & 1.35 & 0.15 & 0.98 & 0.90 \\
\hline
\end{tabular}

\section{Different models and allied statistical parameters are as follows:}

1. Standard length $=-0.56+0.86$ Total length, Correlation coefficient $(r)=0.97$, Coefficient of determination $\left(\mathrm{r}^{2}\right)=0.95$

2. Head length $=0.76+0.15$ Total length, Correlation coefficient $(r)=0.94$ Coefficient of determination $\left(\mathrm{r}^{2}\right)=0.89$

3. Pre dorsal length $=1.92+0.31$ Total length, Correlation coefficient $(r)=0.94$ Coefficient of determination $\left(\mathrm{r}^{2}\right)=0.88$

4. Pre pectoral length $=1.94+0.12$ Total length, Correlation coefficient $(r)=0.85$ Coefficient of determination $\left(\mathrm{r}^{2}\right)=0.72$

5. Pre pelvic length $=1.96+1.13$ Total length, Correlation coefficient $(r)=0.89$ Coefficient of determination $\left(\mathrm{r}^{2}\right)=0.79$

6. Pre anal length $=4.71+0.41$ Total length, Correlation coefficient $(r)=0.96$ Coefficient of determination $\left(\mathrm{r}^{2}\right)=0.92$.

7. Eye diameter $=0.37+0.02$ Total length, Correlation coefficient $(r)=0.67$ Coefficient of determination $\left(\mathrm{r}^{2}\right)=0.40$

8. Snout length $=0.30+0.03$ Total length, Correlation coefficient $(r)=0.76$ Coefficient of determination $\left(\mathrm{r}^{2}\right)=0.58$

9. Maximum body depth $=-0.01+0.16$ Total length, Coefficient of correlation $(r)=0.94$ Coefficient of determination $\left(\mathrm{r}^{2}\right)=0.88$

10. Caudal length $=1.35+0.15$ Total length, Coefficient of correlation $(\mathrm{r})=0.98$ Coefficient of determination $\left(\mathrm{r}^{2}\right)=0.90$. 
Table 3.6: Regression Analysis and Correlation Coefficient between Standard length and Dependent Parameters

\begin{tabular}{|c|c|c|c|c|c|}
\hline S.No. & $\begin{array}{l}\text { Dependent } \\
\text { parameter }\end{array}$ & Intercept (a) & $\begin{array}{c}\text { Regression } \\
\text { coefficient (b) }\end{array}$ & $\begin{array}{c}\text { Correlation } \\
\text { coefficient (r) }\end{array}$ & $\begin{array}{c}\text { Coefficient of } \\
\text { Determination }\left(r^{2}\right)\end{array}$ \\
\hline 1 & Head length & 1 & 0.17 & 0.935958 & 0.87 \\
\hline 2 & Pre-Dorsal Length & 2.77 & 0.33 & 0.894351 & 0.8 \\
\hline 3 & Pre-Pectoral Length & 2.1058 & 0.1421 & 0.851443 & 0.725 \\
\hline 4 & Pre-Pelvic Length & 3.2237 & 0.3317 & 0.867185 & 0.752 \\
\hline 5 & Pre-Anal Length & 5.4692 & 0.4597 & 0.942319 & 0.888 \\
\hline 6 & Eye-Diameter & 0.3938 & 0.0214 & 0.673859 & 0.454 \\
\hline 7 & Snout-Length & 0.3971 & 0.0353 & 0.72125 & 0.52 \\
\hline 8 & $\begin{array}{l}\text { Maximum } \\
\text { depth }\end{array}$ & 0.2118 & 0.1807 & 0.94042 & 0.884 \\
\hline 9 & Caudal Length & 1.71 & 0.16 & 0.917 & 0.84 \\
\hline
\end{tabular}

11. Head length $=1+0.17$ Standard length, Coefficient of correlation $(r)=0.9359$

Coefficient of determination $\left(r^{2}\right)=0.87$

12. Pre Dorsal length $=2.77+0.33$ Standard length, Coefficient of correlation $(r)=0.8943$

Coefficient of determination $\left(\mathrm{r}^{2}\right)=0.8$

13. Pre pectoral length $=2.1058+0.1421$ Standard length, Correlation coefficient $(r)=0.85144$

Coefficient of determination $\left(\mathrm{r}^{2}\right)=0.725$

14. Pre pelvic length $=3.2237+0.3317$ Standard length, Correlation coefficient $(\mathrm{r})=0.8671$

Coefficient of determination $\left(\mathrm{r}^{2}\right)=0.752$

15. Pre anal length $=5.4692+0.4597$ Standard length, Correlation coefficient $(r)=0.9423$

Coefficient of determination $\left(\mathrm{r}^{2}\right)=0.888$.

16. Eye diameter $=0.3938+0.0214$ Standard length, Correlation coefficient $(r)=0.6738$

Coefficient of determination $\left(\mathrm{r}^{2}\right)=0.454$

17. Snout length $=0.3971+0.0353$ Standard length, Correlation coefficient $(r)=0.72125$

Coefficient of determination $\left(\mathrm{r}^{2}\right)=0.52$

18. Maximum body depth $=0.2118+0.1807$ Standard length , Coefficient of correlation $(r)=$ 0.94042 , Coefficient of determination $\left(\mathrm{r}^{2}\right)=0.884$

19. Caudal length $=1.71+0.16$ Standard length, Coefficient of correlation $(r)=0.917$

Coefficient of determination $\left(\mathrm{r}^{2}\right)=0.84$.

20. Eye diameter $=0.2709+0.1247$ Head length, Correlation coefficient $(r)=0.7164$

Coefficient of determination $\left(\mathrm{r}^{2}\right)=0.513$

21. Snout length $=0.3106+0.1823$ Head length, Correlation coefficient $(r)=0.68111$

Coefficient of determination $\left(\mathrm{r}^{2}\right)=0.464$

22. Maximum body depth $=1.6579+1.0187$ Head length, Coefficient of correlation $(r)=0.9685$

Coefficient of determination $\left(\mathrm{r}^{2}\right)=0.938$ 
Table 3.7: Regression Analysis and correlation coefficient between Head length and dependent parameters

\begin{tabular}{clcccc}
\hline SN & Dependent parameter & Intercept (a) & $\begin{array}{c}\text { Regression } \\
\text { coefficient (b) }\end{array}$ & $\begin{array}{c}\text { Correlation } \\
\text { coefficient (r) }\end{array}$ & $\begin{array}{c}\text { Coefficient of } \\
\left.\text { Determination( } \mathbf{r}^{2}\right)\end{array}$ \\
\hline 1 & Eye-Diameter & 0.2709 & 0.1247 & 0.716485 & 0.513 \\
2 & Snout-Length & 0.3106 & 0.1823 & 0.681164 & 0.464 \\
3 & Maximum Body depth & 0.6579 & 1.0187 & 0.968584 & 0.938 \\
\hline
\end{tabular}

Meristic Analysis: On the basis of meristic analysis conducted on 30 specimen of Tor putitora.

The fin formula was summarised as follows:

D - 11(2/9), Pi -14-16, Pii- 9 A-7(2/7), C-22.

\section{Discussion}

The present study on Tor putitora is conducted based on morphometric and meristic analysis. Tor putitora is commonly known as Golden Mahseer. The relationship between total length and related body parts is studied. A positive correlation (Table 5) is found in all the parameters with total length and thus showed significant correlation in body growth. The most highly correlated body parameter with total length is caudal length $(r=0.98)$ and least correlated is eye-diameter $(\mathrm{r}=0.67)$. The most highly correlated body parameter in relation to standard length is pre-anal length $(\mathrm{r}$ $=0.94)$ and least correlated is eye diameter $(r=$ 0.67) (Table 6). The most highly correlated body parameter in relation to head length is maximum body depth $(r=0.96)$ and least correlation with snout length $(r=0.68)$ ( Table 3.7). All relationships were positively correlated which showed isometric growth in all the parts of Tor putitora under natural conditions. Singh and Dobriyal (1983) studied the morphometric characters and their relationships in the hill stream cat fish Pseudecheneis sulcatus (McClelland) collected in the river Alaknanda at Srinagar Garhwal and found no second stock of population. According to Dobriyal and Bahuguna (1987), there was no significant difference in the stock of population of $N$. montanus collected from Khanda stream. Dobriyal et al. (1988) also reported single stock in Noemacheilus denisonii and Noemacheilus multifaciatus from the same stream. Uniyal et al. (2005) also studied the morphometric characters and their relationship in the fish Tor chilinoides at Western Nayar and found no any second stock. Bahuguna (2007) concluded that there was a single stock of the population of Puntius conchonius (Ham-Buch) in Mandal river. Kar and Barbhuia (2010) worked extensively on morphometric and meristic characters of Chocolate mahseer Neolissochilus hexagonolepis and considered 26 morphometric characters. The diagnostic features shows that body of Tor putitora is 
elongated and both profiles (dorsal and ventral) nearly straight and somewhat compressed. Head is bigger than body depth. Mouth small and upper jaw slightly longer than that of lower jaw, Lips thick and fleshy barbells with two pairs. Last unbranched ray of dorsal fin is comparatively strong, smooth and osseous. Pelvic fin contains a scaly appendage. Caudal fin deeply forked. Colour of the side is greenish silvery. Belly silvery to white. Scales are golden with dark base and formed of minute black spot. Pectoral, Pelvic, and Anal fins reddish yellow in colour.

Meristic characters are the countable characters. Dorsal fin having 11 number of rays, Pectoral fin having $14-15$ number of rays, Pelvic fin having 9 number of rays, Anal fin having 7 number of rays, Caudal fin having 22 number of rays, scales above lateral line are 3.5 to 4 in numbers and scales below lateral line is 5 to 3 in numbers. These characters are constant with increase in the length of the fish and makes Fin formula which is similar to the study carried out by Rahman (1989) and Langer et al. (2013) but show deviation from those observed by Zafar et al.(2012) in Tor putitora in foot hills of river Korang, Pakistan which in present case has been observed to be 11(2/9) for dorsal fin rays while the number recorded by Zafar et.al. (op cit) to be 12(4/8) for dorsal fin ray of Tor putitora. Present study on Morphometric and meristic characters concludes that all the specimens collected were having similar characteristics, hence showed no deviation in population. These results will be helpful for research in fishery, management and conservation in least explored tributary of Ravi river.

\section{References}

Bahuguna PK, Joshi HK and Dobriyal AK (2007). Fecundity and sex ratio in Puntius conchonius (Pisces;

Cyprinidae) from Garhwal Himalaya, Environmental Oconservation Journal 8(1-2): $\quad 37-43$.

Desai VR (1973). Studies on Fishery of Tor tor (Ham.) from river Narbada. Proc. Indian. Nat.Sci. Acad. 39 (2b): 228248.

Dobriyal AK and Bahuguna AK (1987). Morphometric character and their relationships in the

hillstream loach Noemacheilus montanus. Him. J. Env. Zool, 1: 23-27.

Dobriyal AK, Bahuguna AK and Singh HR (1988). Morphometric characters and their relationship in two Noemacheilus species from Garhwal Himalaya. Agra. Boil. Res.4(2):21-24.

Jain Sharad K, Agarwal Pushpendra K, Singh Vijay P (2007). Hydrology and Water Resources of India, Springer Science and Business Media, p. 482, ISBN 978-1-4020-5180-7.

Jhingran VG and Sehgal KL (1978). Cold water fisheries of India, Inland Fisheries Society of India, Barrackpore, 239pp.

Joshi CB, Sehgal KL and Shyam Sunder (1978). Observation on the fishery resources of the hill 
streams of Jammu province with special reference to Mahseer and other commercially important species, Indian Journal of Fisheries, 25: 197-206.

Joshi P C (1994). Ecological restoration of water and fish population in the Himalayan Rivers of $\quad$ U.P. $\quad J$. Freshwater Biol., 6(2): 101-107.

Langer S, Tripathi NK and Khajuria B (2013). Morphometric and meristic study of Golden Mahseer (Tor putitora) from Jhajjar stream (J\&K), India. Res. J. Animal, Veterinary and Fishery Sci., 1(7): 1-4.

Rahman A K A (1989). Fresh water fishes of Bangladesh. Zoological Society of Bangladesh. Department of Zoology University of Dhaka.

Rathore V and Dutta S P S (2015). Fish fauna of river $\mathrm{Ujh}$, an important tributary of the river Ravi, District Kathua, Jammu. Environment Conservation Journal, 16: 81- 86.

Sehgal K L (1983). Himalayas Mountain and Men, T.V. Singh and J. Kour (Eds.), Print House Lucknow

(U.P), 225-272.

Singh H R and Dobriyal A K (1983). Morphometric characters and their relationships in the catfish Pseudeche-neis sulcatus. Indian J. Anim. Sci. 53: 541-546.

The National Commission on Agriculture (NCA) 1976. Report on NCA Part III-
Fisheries, pp 8-8. Govt. of India, New Delhi.

Thomas H S (1897). Rod in India, London Mullocks Auctions.

Uniyal S P, Dobriyal A K, Bisht M S and Joshi HK (2005b). Morphometric and meristic analysis of Tor chelynoides (Pisces: cyprinidae) from the river Western Nayar of Garhwal, Central Himalaya. Panjab UnivRes. J. (Sci), Vol. 55: 63-67.

Zafar Muhammad, Nazir A, Akhtar N, Naquei SMHM and Rehman M (2012).

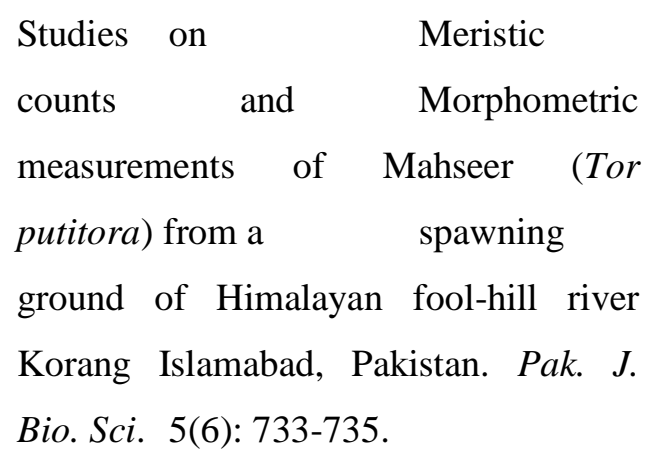
Bio. Sci. 5(6): 733-735. 